\title{
The effect of leisure benefits on leisure satisfaction: Extreme sports
}

\author{
Ersin ESKILER ${ }^{1}$,Yasin YILDIZ $^{2}$,Cihan AYHAN ${ }^{3}$,
}

\author{
${ }^{1}$ Department of Sports Management, Faculty of Sports Sciences, Sakarya University of Applied Sciences, Sakarya, Turkey \\ ${ }^{2}$ Department of Physical Education and Sport Teaching, Faculty of Sports Sciences, Aydin Adnan Menderes University, Aydin, Turkey \\ 3Department of Physical Education and Sport Teaching, Faculty of Sports Sciences, Sakarya University of Applied Sciences, Sakarya, Turkey \\ Address Correspondence to E. Eskiler, e-mail: eeskiler@sakarya.edu.tr
}

\begin{abstract}
In this study, it was aimed to investigate the effect of leisure benefit on leisure satisfaction in extreme sports athletes. In order to determine the leisure satisfaction level of participants, Leisure Satisfaction Scale developed by Beard and Ragheb (1980) and adapted to Turkish by Gökçe and Orhan (2011) was used. Leisure benefit scale developed by Ho (2008) and adapted into Turkish by Akgül, Ertüzün, and Karaküçük (2018) was used to measure the perceived benefit from recreational activities. The conventional sampling method was used for sample selection, and a face-to-face survey method was used for data collection. Descriptive statistics, Pearson Correlation Analysis, and Regression Analysis were used in the analysis of obtained data. A total of 202 people (105 male and 97 female) participated in the study voluntarily. According to the results of the present study, it was determined that there was a positive significant relationship between Leisure benefit and Leisure satisfaction. In addition, it was determined that Leisure satisfaction was predicted by the sub-dimensions of Leisure benefit approximately $84 \%$. This result showed that providing leisure benefits in extreme sports had a significant effect on Leisure satisfaction of extreme athletes.
\end{abstract}

Key words: Extreme sports, Leisure benefits, Leisure satisfaction.

\section{INTRODUCTION}

Nowadays, individuals give importance to leisure by creating some strategies to get rid of work pressure and to renew and strengthen themselves (22). The busy and tiring parts of working life and other compulsory activities has made leisure activities an essential part of life $(18,37)$. Leisure is the remaining time period of the work or other activities that an individual has to keep living $(4,30)$. According to another authors, leisure time is defined as the time part in which one can choose whatever he wants except for tasks and obligations in the official life (32). Individuals in this time period participate in the activities such as recreation, sightseeing, health, being together, excitement, obtaining different experiences, outside or outside the home, in open or closed areas or in active-passive forms, in urban or rural areas (24). At the same time, leisure activities provide leisure benefits in terms of increasing life experiences, realizing oneself (increase in life energy inside them), conscious use and renewal of people's energies $(6,14)$.

The leisure benefit is defined as the positive effects experienced by participants during leisure activities (15). Leisure benefits are a subjective concept and relates to personal experiences (23). This concept has been widely discussed and researched in the fields of physiology, psychology, sociology, and economics. Leisure benefits in these areas were examined as a subjective experience for each individual. These experiences help people to improve their mental and physical health and to satisfy their physical and mental needs (12). Leisure benefits are classified under three headings: physical, psychological and social benefits (20). Physical benefits refer to physical appearance preservation, energy gain, development of abilities for activities, regular resting, fatigue removal, and extra energy release. Psychological benefits include relief from life pressures, emotional relaxation, creative thinking, relaxation of mind and body, and enjoyment of life. Social benefits include the creation of new friendships and relationships, to be considered by other people, understanding the feelings of the people and gaining the trust of others (12). While the characteristic, social background and leisure environment affect the peoples' motivation, attitude, preference, and expectation for participating in a leisure activity, people 
participating to the leisure activities has many benefits in return (23). Therefore, it is possible to say that there was a mutual exchange.

The benefits of participating in leisure activities are unlimited. Individuals who participate in activities gain benefits in terms of psychological, physiological, educational, social and relaxation. In addition, fatigue, anxiety and job stress decrease (36, 38). Individuals enjoying leisure activities gain a leisure satisfaction (5). Leisure satisfaction is the positive satisfaction or emotions that a person receives as a result of participation in leisure activities (8). These activities, in addition to strengthening the connections of individuals with life, provide health and spiritual personality development (2). In accordance with the benefits of leisure activities, it is likely that individuals who are satisfied with leisure are happy and healthy.

People often want to participate in leisure activities to meet their psychological needs related to feel good and happy. Therefore, the more leisure activities meet the basic needs, the higher it contributes to the subjective well-being of individuals (26). Newman et al., (2014) explained this link as the bottom-up spillover theory of subjective well-being (31). According to this theory, if a person satisfied with a leisure activity, this satisfaction contributes to the leisure life satisfaction and in return to the subjective well-being of a person (35). It was thought that determining the effects of leisure benefits of the athletes participating in extreme sports on leisure satisfaction was important. Therefore, the aim of this study was to investigate the effect of leisure benefits on leisure satisfaction in extreme sports athletes.

\section{MATERIAL AND METHOD}

Because it is easily accessible by the researcher, the study universe was determined as extreme athletes in Istanbul. A total of 202 extreme athletes (105 male (52\%) and 97 female (48\%) participated in the study voluntarily. The average age of the participants was $23.48 \pm 6.36$ (years).

The questionnaire form was applied to the sample mass, which was determined by conventional sampling method, between 28 January 2018 and 15 March 2018 by using face to face survey technique. In this study based on quantitative research method, general screening model was used. A Total of 48 items were used in the questionnaire form.
In order to determine the leisure satisfaction level of participants, Leisure Satisfaction Scale developed by Beard and Ragheb (1980) (8), and adapted to Turkish by Gökçe and Orhan (2011) was used. Leisure Satisfaction Scale in 5-point rating ( $1=$ Almost Never True, 4, $5=$ Almost Always True) 24 items and consists of six sub-dimensions as Psychological (4 items), Educational (4 items), Social (4 items), Relaxation (4 items), Physical (4 items) and Aesthetics (4 items). Items 1-4 were related to the psychological sub-dimension, 5-8 educational subdimension, 9-12 social sub-dimension, 13-16 relief sub-dimension, 17-20 the physical sub-dimension, and 21-24 the aesthetic sub-dimension. In addition, leisure satisfaction scale total scores were calculated as arithmetic means of all items (17).

The leisure benefit scale developed by Ho (2008) (19), and adapted to Turkish by Akgül, Ertüzün, and Karaküçük (2018) was used to measure the perceived benefit of participants from leisure activities. Leisure Benefit Scale is a 5-point Likert type $(1=$ Strongly Disagree, ..., $5=$ Strongly Agree), has 24 items and 3 sub-dimensions as Physical benefits ( 7 items), Psychological benefits ( 8 items) and Social benefits (9 items). Items 1-7 were related to sub-dimension of physical benefits, 8-15 subdimension of psychological benefits, and 16-24 subdimension of social benefits (1).

\section{INTERPRETATION OF ANALYSIS AND FINDINGS}

Descriptive statistics, Correlation, and Regression analysis were used to analyze the data. Durbin-Watson coefficient values for the regression model, binary correlations (binary $\mathrm{r}<0.80$ ), tolerance values $(1-R 2>0.20)$, variance magnification factor $(\mathrm{VIF}=[1 /(1)]-\mathrm{R} 2)]<10)$ and the highest status index value $(\mathrm{CI}<30)$ were examined and it was determined that there was no autocorrelation problem between the variables. For the social benefit sub-dimension of the Cronbach $\alpha$ internal consistency values of each factor was determined as $\alpha=0.92$, for the physical benefit sub-dimension $\alpha=0.91$ for the psychological benefit sub-dimension $\alpha=0.91$, for the sum of the leisure benefit scale $\alpha=0.97$ and for leisure satisfaction scale $\alpha=0.97$ and was found to be greater than the recommended value of $0.70(3,10)$. Significance was set at $\mathrm{p}<0.01$. 
Table 1. The Relationship between Participants' Leisure Satisfaction and Leisure Benefit Subdimensions

\begin{tabular}{|c|c|c|c|c|c|c|}
\hline \multicolumn{3}{|c|}{ Variables } & 1 & 2 & 3 & 4 \\
\hline \multirow{2}{*}{\multicolumn{2}{|c|}{$\begin{array}{l}\text { Level of Total Leisure } \\
\text { Satisfaction }{ }^{1}\end{array}$}} & $\mathrm{r}$ & 1 & .840 & .843 & .868 \\
\hline & & $\mathrm{p}$ & & $.001^{* *}$ & $.001^{* *}$ & $.001^{* *}$ \\
\hline \multirow{6}{*}{ 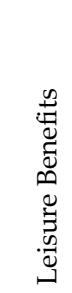 } & \multirow{2}{*}{$\begin{array}{l}\text { Physical } \\
\text { Benefits }^{2}\end{array}$} & $\mathrm{r}$ & & 1 & .859 & .784 \\
\hline & & $\mathrm{p}$ & & & $.001^{*+}$ & $.001^{* *}$ \\
\hline & \multirow{2}{*}{$\begin{array}{l}\text { Psychological } \\
\text { Benefits }^{3}\end{array}$} & $\mathrm{r}$ & & & 1 & .777 \\
\hline & & $\mathrm{p}$ & & & & $.001^{* *}$ \\
\hline & \multirow{2}{*}{ Social Benefits 4} & $\mathrm{r}$ & & & & 1 \\
\hline & & $\mathrm{p}$ & & & & \\
\hline
\end{tabular}

According to the correlation analysis, high positive relationship between leisure benefit subdimensions (physical, psychological and social benefit) was determined. In addition, it was

Linear regression analysis was used to determine the effect of leisure benefit levels of the participants on leisure satisfaction. As a result of the analysis, it was determined that leisure benefit sub-dimensions predicted leisure satisfaction approximately $84 \%$ (adj. R2 $=.835$ ). Furthermore, independent variables were found to affect the dependent variable positively and significantly $(\mathrm{p}$ $<.001)$. In addition, the highest effect on leisure satisfaction was determined as a social $(\beta=.468, \mathrm{p}$ $<.01)$, psychological $(\beta=.277, \mathrm{p}<.001)$, and physical benefit $(\beta=.235, \mathrm{p}<.001)$, respectively.

\section{CONCLUSION AND EVALUATION}

According to the primary findings of the study, it was determined that there was a high positive relationship between all sub-dimensions of leisure benefits and leisure satisfaction. This result indicates that the higher leisure satisfaction level the participants have, the more leisure benefit levels will increase. Thanks to participation in leisure activities, individuals move away from work pressure and monotonous lifestyle and their social environment and lifestyle change (13). Individuals gain psychological, physiological, social, educational and aesthetic benefits through recreational activities. These benefits increase the level of satisfaction of individuals (23). Lewis, Cooper, Smithson, and Dyer (2001) have reported that recreation policies are an important way to reduce work pressure and a significant source of leisure satisfaction (27). determined that the leisure benefits sub-dimensions (physical benefit $\mathrm{r}=.840$, psychological benefit $\mathrm{r}=$ .843 and social benefit $\mathrm{r}=.868$ ) were highly correlated with leisure satisfaction.

Table 2. The Effect of Leisure Benefit Sub-Dimensions on Leisure Satisfaction Level

Dependent Variable: Level of Total Leisure Satisfaction

\begin{tabular}{llllll}
\hline Variables & $\mathrm{B}$ & $\begin{array}{l}\text { Standard } \\
\text { Error }\end{array}$ & $\beta$ & $\mathrm{t}$ & $\mathrm{p}$ \\
\hline (Constant) & .205 & .112 & & 1.819 & .070 \\
$\begin{array}{l}\text { Physical } \\
\text { Benefits }\end{array}$ & .198 & .051 & .235 & 3.917 & $.001^{* *}$ \\
$\begin{array}{l}\text { Psycholog } \\
\text { ical }\end{array}$ & .270 & .058 & .277 & 4.678 & $.001^{* *}$ \\
$\begin{array}{l}\text { Benefits } \\
\begin{array}{l}\text { Social } \\
\text { Benefits }\end{array}\end{array}$ & .447 & .047 & .468 & 9.588 & $.001^{* *}$ \\
\hline $\begin{array}{l}\mathrm{R}^{2}=.837, \text { adj.R } \mathrm{R}^{2}=.835 \\
\mathrm{~F}=339.94, \mathrm{p}=.001\end{array}$ & & & & \\
\hline
\end{tabular}

According to the main findings of the study, the results of the regression analysis to determine the effect of the leisure benefit levels on leisure satisfaction shows that the leisure benefit subdimensions predicted the leisure satisfaction by approximately $84 \%$ and positively. It can be thought that the remaining $14 \%$ of the missing time to complete the leisure satisfaction may constitute other variables (motivation, coping with participation in activities, level of care, life satisfaction, subjective well-being, and socioeconomic status, etc.).

The recreational activities that the extreme athletes participated can contribute to discovering their special abilities, experiencing the sensation of curiosity, struggle and success and enjoying the life. These benefits, which they achieve in line with their expectations, can ensure that they are satisfied with the activities they participate in. Chang (2002) has reported that the benefits of participation in leisure activities increased the sense of satisfaction of individuals towards activities and their behavioral motivation, and showed a positive attitude towards the activity and strengthened their intention to rejoin (11). Yang (2006) has reported that recreational activities will contribute to the preservation and maintenance of mental and physical health of individuals, the development of teamwork and the increase of positive effect on daily work (40). Kelly and Godbye (1992) have reported that individuals can satisfy their daily life and leisure needs through recreational activities (25). These results show that the increase in the levels of 
benefits that achieved as a result of their participation in the activities will contribute to the increase of their behavioral intentions and satisfaction levels.

Some researchers have reported that leisure benefits are effective in achieving feelings of satisfaction for individuals in their leisure activities. Accordingly, benefits such as body weight control, physical health protection, and energy regeneration are effective in satisfying individuals' physical characteristics $(7,9,33)$. Benefits such as the feeling of freedom, the development of self-efficacy and the reduction of the earthquake-anxiety-nervous system are effective in the psychological satisfaction of the individual $(12,21,29,39)$. Benefits such as the discovery of new information and technologies, originality and the desire for potential talent are effective in educational satisfaction $(7,12)$.

The positive changes in the mood are effective in satisfying the stresses of work and everyday life, reducing energy, improving energy efficiency and improving work efficiency, reducing stress and anxiety $(7,12)$. The benefits such as satisfying the spiritual needs of the individual and enriching his life are effective in aesthetic satisfaction (7). The benefits of social and cultural identity acquisition, family bond development, social relations and the development of skills are effective in social satisfaction $(7,9,28)$.

As a result, it was found that the leisure benefits were an important determinant of leisure satisfaction. The physical, psychological, and social benefits of individuals as a result of their participation in leisure activities (34) help to meet their expectations from recreational activities. In this context, the happiness and satisfaction of participation in recreational activities contribute to the development of personal satisfaction (39). Finally, individuals need to be directed to activities that provide leisure benefits to increase their leisure satisfaction. Thus, individuals can be increased leisure satisfaction levels.

\section{REFERENCES}

1. Akgül, B. M., Ertüzün, E., Karaküçük, S. Rekreasyon Fayda Ölçeği: Geçerlilik ve Güvenirlik Çalışması. Gazi Beden Eğitimi ve Spor Bilimleri Dergisi, 2018; 23(1): 25-34.

2. Akkaya, S. “Üniversite Öğrencilerinin Popüler Kültür Etkinlikleri Ve Boş Zaman Alışkanlıkları", Yüksek lisans Tezi, Anadolu Üniversitesi Sosyal Bilimler Enstitüsü, Eskişehir, 2008.
3. Altunişik, R., Coşkun, R., Bayraktaroğlu, S., Yildirim, E. Sosyal bilimlerde araştırma yöntemleri. Sakarya Yayıncılık, Sakarya, 2007: 226.

4. Ayhan, C., Ekinci, N., Yalçın, İ., Yiğit, Ş. Investigation of Constraints that Occur during Participation in Leisure Activities by High School Students: A Sample of Turkey. Education Sciences, 2018; 8(2): 86-94.

5. Ayhan, C., Eskiler, E., Ekinci, N.E., “Extreme Sporcuların Serbest Zaman Tatmin Düzeylerinin Çeşitli Değişkenler Açısından İncelenmesi," International Academic Sport Research Congress, 134-141. Batumi, Georgia, 2018.

6. Ayhan, C., Eskiler, E., Soyer F., “Aktif Sporcuların Rekreatif Etkinliklere Katılımlarına Engel Oluşturabilecek Faktörlerin Yaşam Tatmini ve Yaşam Kalitesi Üzerine Etkisi," Erpa Int.Congresses on Education, Hungary, 164-175, Budapest, Hungary, 2017.

7. Bammel, G., Burrus-Bammel, L.L. Leisure and Human Behavior. Dubuque, Iowa: W.C. Brown, 1996.

8. Beard J.G., Ragheb M.G. Measuring Leisure Satisfaction. Journal of Leisure Research, 1980; 12 (1): 20-33.

9. Bright, A. D. The role of social marketing in leisure and recreation management. Journal of Leisure Research, 2000; 32(1): 12-18.

10. Büyüköztürk, Ş. Veri analizi el kitabı (22. Baskı). Ankara: Pegem Akademi, 2016.

11. Chang, C.C. "The study of leisure attitude and leisure participation in elementary school students - example from Pingtung County." National Ping-Tung University of Education, 2002.

12. Chen, Z.Y. "The study of elementary teachers' leisure participation, experience in leisure benefits, and work satisfaction in Taipei County." National Taiwan Normal University, 2001.

13. Damanedier, J. Sociology of leisure. New York: Elsevier North-Holland, 1974.

14. Detmer, J.L. Distributions in utilizing leisure skills and positive experiences as a component of treatment progress in men who are civilly committed sexual offenders. Published doctoral dissertation. Capella University, 2010.

15. Driver, B.L. The North American experience in measuring the benefits of leisure. In Proceedings National Workshop on Measurement of Recreation Benefits. Bandoora, Australia: Phillip Institute of Technology, 1990; 1-57.

16. Driver, P.J. Brown G.L. Peterson (Eds.). Benefits of leisure. Stage College, PA: Venture Publishing, 2001; 461-473.

17. Gökçe, H. Orhan, K. Serbest Zaman Doyum Ölçeğinin Türkçe geçerlilik güvenirlik çalışması, Spor Bilimleri Dergisi, 2011; 22(4): 139-145.

18. Gumus, H., Isik, O. The relationship of physical activity level, leisure motivation and quality of life in candidate teachers. International Journal of Progressive Education, 2018; 14(5): 22-32.

19. Ho, T.K. "A study of leisure attitudes and benefits for senior high school students at PingTung City and country in Taiwan", (Unpublished doctoral dissertation). United States Sports Academy, Daphne, AL, 2008 
20. Hung, H.J. A study on leisure benefits breaking through leisure activities. Journal of National Taiwan Normal University, 2012; 3(4): 77-92.

21. Iso-Ahola, S.E. A psychological analysis of leisure and health. In J. Haworth (Ed.), Work, leisure and well-being. New York: Routledge, 1997.

22. Iwasaki, Y., Mannell, R.C. Hierarchical dimensions of leisure stress coping. Leisure Sciences, 2000; 22(3): 163-181.

23. Kao, C.H. A three-factor model of leisure benefits. Journal of Outdoor Recreation Study, 1995; 8(1): 67-78.

24. Karaküçük, S. Rekreasyon (Boş Zamanları Değerlendirme), Gazi Kitabevi: Ankara, 2008.

25. Kelly, J.R., Godbye, G.C. Sociology of leisure. State College, PA: Venture. College, PA: Venture Publishing, 1992; 121-144.

26. Lee, D.J., Kruger, S.,Whang, M.J., Uysal, M., Sirgy, M.J. Validating a customer well-being index related to natural wildlife tourism. Tourism Management, 2014; 45: 171-180.

27. Lewis, S., Cooper, C., Smithson, J., Dyer, J. Flexible futures: Flexible working and work-life integration. Report on phase two. London: Institute of Chartered Accountants in England and Wales, 2001.

28. Lin, S.H. A Study on Influence of Interpretation Effects to Experience of Leisure Benefits-A Case Study of Hiking. Published doctoral dissertation. Taiwan Norm al University, 2002.

29. Mannell, R.C., Stynes, D.J. A retrospective: The benefits of leisure. Benefits of Leisure, 1991; 16: 461-473.

30. Mull, R.F., Bayless, K.G., Ross, C.M., Jamieson, L.M. Recreational Sport Management. Third Edition, Human Kinetics, USA, 1997.

31. Newman, D.B., Tay, L., Diener, E. Leisure and subjective well-being: a model of psychological mechanisms as mediating factors. Journal of Happiness Studies, 2014; 15: 555-578.

32. Öksüz, E., Özmaden, M. The research on the determination of evaluation leisure time activities problems of the students who stay both Balikesir KYK and the special hostels. Journal of Physical Education \& Sports Science, 2016; 10(1): 71-79.
33. Parry, D.C. Shaw, S.M. The role of leisure in women's experience of menopause and mid-life. Leisure Science, 1999; 21: 205-218.

34. Pichly, A. Individuals can benefit physically, mentally, emotionally, spiritually and socially from a comprehensive leisure education program implemented in the schools during childhood. A research project report submitted in partial fulfillment of the requirements for the successful completion of RLS 209. 2002.

35. Sirgy, M.J., Uysal, M., Kruger, S. Towards a benefits theory of leisure well-being. Applied Research in Quality of Life, 2017; 12(1): 205-228.

36. Soyer, F., Yıldız, N.O., Demirel, D.H., Serdar, E., Demirel, M., Ayhan, C., Demirhan, O. Üniversite öğrencilerinin rekreatif etkinliklere katılımlarına engel teşkil eden faktörler ile katılımcıların yaşam doyumları arasındaki ilişkinin incelenmesi. Journal of Human Sciences, 2017; 14(2): 20352046.

37. Tel, M., Köksalan, B. Öğretim Üyelerinin Spor Etkinliklerinin Sosyolojik Olarak İncelenmesi (Doğu Anadolu Örneği). Fırat Üniversitesi Sosyal Bilimler Dergisi, 2008; 18(1): 261-278.

38. Tinsley H.E., Tinslry D.J. A theory of the attributes, benefi ts, and causes of leisure experience. Leisure Sciences, 1986; 8(1): $1-45$.

39. Wankel, L.M., Berger, B.G. The personal and social benefits of sport and physical activity. In B. L. Driver, P. J. Brown, \& G. L. Peterson (Eds.), Benefits of leisure . State College, PA, US: Venture Publishing, 1991.

40. Yang, Y.S. A Study on the Relationship among Participation of Leisure Activities, Leisure Constraints and Well-Being of the Students in National Changhua Senior School of Commerce. Ta-Yeh University, Taiwan, 2006. 